\title{
Seroprevalence and risk factors associated with West Nile infection in human in Madagascar: a cross-sectional serological survey
}

\author{
Marie-Marie Olive \\ Institut Pasteur de Madagascar \\ Anaïs Broban \\ Institut Pasteur de Madagascar \\ Institut Pasteur de Madagascar \\ Anne-Claire Dorsemans \\ Institut Pasteur de Madagascar \\ Jean-Pierre Ravalohery \\ Institut Pasteur de Madagascar \\ Seta Andriamamonjy \\ Institut Pasteur de Madagascar

\section{Fanjasoa Rakotomanana} \\ Institut Pasteur de Madagascar \\ Christophe Rogier \\ Primum vitare ! D'abord prévenir ! \\ Jean-Michel Heraud \\ Institut Pasteur de Madagascar
}

Soa Fy Andriamandimby ( $\sim$ soafy@pasteur.mg )

\section{Research Article}

Keywords: West Nile virus, serological survey, humans, Madagascar

Posted Date: April 29th, 2021

DOI: https://doi.org/10.21203/rs.3.rs-388847/v1

License: (c) (i) This work is licensed under a Creative Commons Attribution 4.0 International License.

Read Full License 


\section{Abstract}

Background: West Nile virus (WNV) is a vector-borne virus maintained through an arthropod-borne transmission cycle involving bird hosts and Culex mosquito species. The disease affects humans in North America, Europe, Africa and Indian Ocean islands including Madagascar. In Madagascar, despite the surveillance of WNV, unreported WNV encephalitis (WNE) are suspected. In order to improve WNE surveillance efficiency and optimize the available resources we aimed to estimate WNV human seroprevalence in different areas of the island, and to identify the environmental factors and areas favorable to WNV transmission in human.

Methods: Between 2011 and 2013, during a national cross-sectional serological survey 1,680 individuals were sampled. Sera were tested for IgG directed against WNV using ELISA and Hemagglutination Inhibition assays. Then, we analyzed human serological results using Generalized Linear Mixed Models, with the individual serological status as the response, and environmental variables and human related factors as explanatory variables.

Results : The overall human WNV seropositivity rate was 12.7\% (95\% $\mathrm{Cl}$ [11.2-14.4]). Human seroprevalence was positively associated with humid environment $(p<0.005)$ whereas cold and highlands environment had a significant negative effect on seroprevalence $(p<0.001)$. Outdoor work had also a significant positive effect on seroprevalence $(p<0.01, \mathrm{OR}=1.99)$.

Conclusions: Our results indicate a heterogeneous circulation of WNV in human and highlights that humid environment of the northwestern part of the island is at-risk for WNV circulation whereas cold environment of the highlands is not favorable for WNV transmission in human. The identification of atrisk environments for WNV circulation in humans should help to improve the surveillance of the disease in Madagascar and is a first step to target future studies on acute encephalitis.

Trial registration: The protocol was approved by the Malagasy competent authorities, the Malagasy Ethic National Committee (authorization N066/MSAMP/CE, 26th July 2011).

\section{Background}

Madagascar is a large island of the South West Indian Ocean, well known by its exceptional flora and fauna biodiversity and its high diversity of bioclimatic regions. This variety of bioclimatic regions is now known to harbor different epidemiological mechanisms of transmission of vector-borne diseases such as plague, malaria and Rift Valley fever (RVF) [1-4]. These variety of epidemiological mechanisms are likely linked to close relationship between the vectors of the diseases and their environment but also human behavior and hosts distribution [4]. Amongst vector borne diseases circulating in Madagascar, several arboviruses have been detected including RVF, Dengue, Chikungunya and West Nile [5-9].

West Nile virus (WNV) belonging to Flaviviridae family affects mainly human and horses in North America, Europe, Africa and Indian Ocean islands. The virus is maintained through an arthropod-borne 
transmission cycle involving bird hosts (e.g. Charadriiformes and Passeriformes orders) and Culex mosquito species. Humans and horses are considered as incidental dead-end hosts [10]. In humans, symptoms of infection range from mild fever to severe or fatal neuroinvasive disease, including encephalitis [11]. In Madagascar, human infection with WNV has been documented [8, 12, 13], and the virus has been detected in horses, domestic birds and different mosquito species [14-16]. Since former studies suggested a heterogeneous circulation of WNV in Madagascar island [8, 13], WNV distribution at the national scale is poorly documented. Moreover, the high seroprevalences observed in some area suggest that WNV infection reports are probably underestimated $[12,15]$.

A surveillance sentinel network of fevers has been implanted in Madagascar in 2007 aiming at rapidly detect an epidemic and identify circulating arboviruses [17]. Despite the monitoring of WNV circulation amongst this surveillance system, unreported WNV encephalitis (WNE) cases are suspected [12]. In order to improve WNE surveillance efficiency and optimize the available resources by using a targeting strategy, the identification of at-risk environments is essential. Herein, the objectives of our study were to estimate WNV human seroprevalence in different areas of the island and to identify the environmental factors favorable to WNV transmission in human.

\section{Methods}

\section{Dataset}

The dataset contained data from a national cross-sectional serological survey conducted from November 2011 to April 2012 and from October 2012 to May 2013 in 56 cities or villages (Fig 1). The protocol of sampling has been previously described $[4,18]$. In each of the 56 sites, 30 adults were randomly chosen and sampled on a voluntary basis (Fig 1). Socio-professional categories (butcher, farmer, health worker, teacher, student, administrative worker, retired), worker in contact with water or forest and contact with poultry were documented through a dedicated questionnaire.

The protocol was approved by the Malagasy competent authorities, the Malagasy Ethic National Committee (authorization N066/MSAMP/CE, 26th July 2011). After reading of the informed consent letter, written and oral consent was obtained from volunteering individuals. Participants were sampled by qualified investigators and the data were analyzed anonymously.

Figure 1: Sampling sites and IgG serological results.

\section{Covariates}

Assuming that (1) WNV is likely to be endemic in Madagascar island [14,16,19] and (2) the introduction risk of WNV by migratory birds is low [16], we considered only covariates potentially involved in the amplification cycle of WNV and not those involved in the introduction events. The following covariates were selected according to their putative influences on mosquitoes' and wild birds' density, their population dynamics, and risk of contact with human: 
- Surface covered by water bodies and landscape categories (e.g. rural/urban area, agricultural area, forest, shrubland). Density and population dynamics of vectors and presence of reservoir birds are influenced by environmental factors such as climate, presence of water bodies and other landscape features $[16,20]$. Culex mosquito genus is considered as the principal mosquito vector responsible for the transmission of WNV [21]. The presence of this genus is associated with a large variety of temporary and permanent water bodies, including rice fields, [16,19,22-24];

- Rainfall, Normalized Difference Vegetation Index (NDVI) and temperatures. The WNV infection risk has been shown to vary according to rainfall, NDVI and temperatures [25,26];

- Poultry contact and density. WNV is known to circulate amongst poultry $[27,28]$;

- Human related factors: habitat, gender, profession (working environment, contacts with live poultry) and socio-economic status (SES) are potential risk factors for WNV infection in human [29-31].

Human related factors. Age of the individuals was categorized in 4 groups: [18 to 26], [27 to 37], [38 to 46 ] and more than 47 years old. Sampling sites were divided as urban, sub-urban and rural sites according the work of Andriamandimby et al. [18] (Fig 1). Working environments were characterized by household, indoor and outdoor environments. Daily or weekly work in rice field was considered as a frequent contact with rice field. As well, daily or weekly work in forest was considered as a frequent contact with forest environment. Contact with poultry was categorized according the number of poultry owned by household. We considered that a frequent contact occurs when household owned 11 or more poultry. The SES of each individuals were previously categorized by Andriamandimby et al. using principal component analysis and hierarchical cluster analysis [18]. Three cluster were used to describe SES : low socio economical level described by wooden combustion use, roof made in plants, light of the petroleum lamp, dirt floor in the bedroom and not equipped with toilet; intermediated socio-economical level described by wood charcoal combustion, sheet roof, electricity light, TV and cement floor and high socio-economical level described by computer owning, flash toilet owning, internet access, car and refrigerator owning.

Poultry density. For each of the 1,578 Malagasy communes, poultry density was estimated using the global distribution maps for poultry produced by the Food and Agriculture Organization of the United Nations [32]. Poultry density of the related communes was classified in 4 categories: below 15.6, [15.6 to 37.2], [37.3 to 75.9$]$ and 76 and more.

Environmental variables. As environmental variables, we used data previously published and characterizing Malagasy environment through an integrated analysis [4]. In this study dedicated to RVF, the environment of the 1,578 Malagasy communes were characterized through a Multiple Factor Analysis (MFA) using climatic variables (the annual means of day and night LST, the annual mean and seasonality of precipitation) and landscape variables (the percentage of the surface of the commune covered by each landscape category and the annual mean and seasonality of NDVI). The value of each factor was computed for each of the Malagasy communes. Four MFA factors were described [4]:

- Factor 1 opposed dry environments in south-west to wet environments in the east of Madagascar; 
- Factor 2 opposed cold environments in the highlands to warmer environments in the north-west and south of the island;

- Factor 3 opposed areas with high rainfall in the middle-west to areas with low rainfall in the southwest of Madagascar;

- Factor 4 opposed humid areas situated in the north-western part and eastern coast to dry environment in the center and south of the island.

\section{Laboratory analysis}

Due to potential cross-reactivity with other viruses from the Flaviviridae family, the samples were tested for the presence of both WNV and dengue virus antibodies.

Enzyme-Linked ImmunoSorbent Assay (ELISA) analysis. The serum samples were first tested for IgG antibody using ELISA as previously described [33]. Serum samples diluted at 1/100 were incubated on plates coated the day before with crude antigens (cellular antigens, donation from the Institut Pasteur of Laos). Conjugate anti-human IgG peroxydase-marked (Jackson Immunoresearch Europe LTD) was used to detect IgG. On each plate, a positive control was tested, as well as three negative controls.

Hemagglutination Inhibition $(\mathrm{HI})$ analysis. $\mathrm{HI}$ tests were performed according to Clarke and Casals protocol [34]. Antigens for WNV and the four serotypes of dengue virus were produced at IPM, according to the sucrose-acetone extraction method [35]. Titers of antigen were checked at each experiment and titers obtained were corrected according to it.

Discrimination of positive samples. Positive sample on ELISA against WNV (Optical Density (OD) $>0.02$ ) were tested using $\mathrm{HI}$ assays. In addition, due to potential cross-reactivity with other viruses from the Flaviviridae family, positive samples on ELISA against Dengue virus (OD $>0.08$ ) were also tested for WNV using HI. A sample was considered positive for WNV if its titer in $\mathrm{HI}$ was at least of 1:80. To overcome cross-reactivity, if a sample had titers against the four Dengue virus serotypes higher than for WNV, then this sample was considered as positive for Dengue virus and consequently, negative for WNV. That corresponded to an implicit hypothesis that the seropositivity for the 5 viruses was deemed improbable, given the estimated low probability of these 5 co-infections.

\section{Statistical analysis}

As a first step, univariate analyses of association between suspected risk factors and human WNV serological status were undertaken using Chi square tests for categorical factors and generalized linear models for quantitative factors. Risk factors with significance level $\leq 0.20$ were then included as explanatory variables in generalized linear mixed models (GLMMs), with human individual serological status as response. To account for interdependency of serological status of individuals sampled in the same locality, the commune administrative unit were included in the models as a random effect. In the models, it was assumed that the relationships between serological prevalence and quantitative factors were linear on the logit scale. Multicollinearity among variables was assessed using Variance Inflation 
Factors (VIF), we assumed that a VIF under 10 did not reveal any multicollinearity [36]. Collinear variables were not included in a same model. The selection of the best models was based on the Akaike Information Criterion (AIC). A multi-model inference approach was used to estimate Model-Averaged Fixed Effects (MAFE; full average) and the weight of each explanatory variable [37]. Within the set of models tested, only those with an AIC within 2 units difference from the best model were considered [37]. Internal validity of sets of models was evaluated using the Receiver Operating Characteristic curve method [38].

Data analyses were performed using R software package version 3.0.1 [39-44].

\section{Results}

\section{Description of data and univariate statistical analysis}

Overall, 1,680 individuals were sampled. Descriptive analyses of the data are presented in the Table 1. Age of volunteers ranged from 18 to 99 years (mean age 37.6 years) with a male/female ratio of 1.03 . A total of $27 \%$, living in urban areas, $30 \%$ in sub-urban areas and $43 \%$ in rural areas (Fig 1 ). About $50.4 \%$ of the individuals were classified as low SES, $44.4 \%$ as intermediate and $5.2 \%$ as high. About $55 \%$ of the individuals work outdoor, $30 \%$ indoor and $15 \%$ at the household. Frequent contact with poultry has been recorded for $30 \%$ of the individuals. We noted that $38 \%$ and $31 \%$ declared working frequently in rice field and forest respectively.

MFA factor values of the 48 communes ranged from -1.86 to 3.29 (Factor 1), -1.87 to 2.77 (Factor 2), -5.08 to 1.75 (Factor 3 ) and -0.75 to 4.51 (Factor 4 ).

Overall, the human WNV seropositivity rate was 12.7\% (95\% Cl [11.2-14.4]; Table 1). Frequent work in ricefield or forest, habitat, poultry density category, working environment, Factor 1, Factor 2, Factor 3 and Factor 4 were statistically associated with human seroprevalence by univariate analysis $(p \leq 0.20$; Table 1) and thus included in a multivariate model.

Table 1: Descriptive and univariate analyses.

\section{Multivariate analysis}

The multicollinearity test did not detect any correlation $(\mathrm{VIF}<3)$ between variables included in the multivariate analysis. According to AIC, 10 models were considered as suitable for describing seroprevalence in humans and thus were analyzed using a multi-model inference approach. These models included working environment, frequent working in rice-field, frequent contact with poultry, poultry density, Factor 1, Factor 2, Factor 3 and Factor 4 as explanatory variables (Table 2). Factor 4 had a significant positive effect on seroprevalence $(p<0.005$, weight $=1)$ whereas Factor 2 had a significant negative effect on seroprevalence $(p<0.001$, weight=1). Outdoor work had a significant positive effect on seroprevalence $(p<0.01$, weight=1) with an Odd-Ratios of 1.99 (95\% Cl [1. 23-3.23]). The other variables were not significantly associated with human seroprevalence. 
Internal validity of human set of models were satisfactory with an Area Under the Curve of $0.81(95 \% \mathrm{Cl}$ [0. 78-0.84]).

Table 2: Results from the multi-model inference approach for dataset analysis.

\section{Discussion}

In Madagascar, WNV circulation has already been described several times [8,12,13]. Our study brings recent and national-wide distribution of its circulation in human. The overall human seroprevalence was estimated at $12.7 \%$ (95\% $\mathrm{Cl}$ [11.2-14.4]). This relatively high result is not surprising since WNV seroprevalence in Madagascar was estimated at $46.2 \%$ in horses in 2010 [14], and at $29.9 \%$ and $33.8 \%$ in human $[8,13]$.

The overall seroprevalence observed is higher compared to other African countries such as Union of the Comoros (7.3\%), Kenya (9.5\%), and Cameroon (6.6\%) but lower than adult seroprevalence in Ghana (27.9\%) [45-48].

Our results showed that WNV has circulated in all the island, though with lower seroprevalences in the highlands, as suggested previously in 1990 and $2003[8,49]$. This heterogeneous circulation seems to be linked with environmental factors. Indeed, our results showed that higher circulation is associated with high value of Factor 4 (large surface of permanent wetlands, marshlands and irrigated lands) which suggests that WNV circulation in human is positively associated to humid environment. These environments are mainly situated in the north-western part of Madagascar and are favorable to Culex mosquitoes as well as water birds hosts of WNV $[16,23]$. These results are consistent with the known atrisk environment for WNV circulation in Europe, Tunisia and the United States of America [25,50-52]. Conversely, cold environments mainly situated in the highlands (Factor 2 ) seem to be protective against WNV infection for human. A previous study showed that risk for WNV infection decrease with increasing elevation [52].

Regarding human individual related factors, the absence of significant relationship between age and seroprevalences, first supports the hypothesis of a non-endemic circulation of WNV in human population. Indeed, if the virus was circulating endemically in humans, a positive association of seroprevalence with age would be observed. Since the introduction of WNV through migratory birds in Madagascar seems to be unlikely [16], we can suggest that WNV circulates endemically between birds and mosquitoes and that human are occasionally infected by the virus. Secondly, the seroprevalence is higher in individuals working outdoors. This is not surprising since the persons working outside are more exposed to exophagic mosquitoes and several Culex WNV vector species are known to have this behavior [28,54].

The observed heterogeneous circulation of WNV in human also suggests that WNV transmission is different according to ecoclimatic regions. These environmental-associated mechanisms of transmission could be modulated by (1) the presence of bird hosts, (2) the presence of vectors and (3) the vector competency. To date, 16 mosquito species have been found naturally infected by WNV in Madagascar, 
including four Anopheles (Anopheles coustani, An. pauliani, An. brunnipes, An. maculipalpis), one Mansonia (Mansonia uniformis), one Aedeomyia (Aedeomyia madagascarica), four Aedes sp. (Aedes albocephalus, Ae. madagascarensi, Ae. circumluteolus, Ae. aegypti) and four Culex species (CX. quiquefasciatus, $C x$. scottii, Cx. tritaeniorhynchus, Cx. Univittatus; [16]. Some of these species are specifically distributed in some regions of Madagascar and others are found in all the island [23]. However, the competency of a same mosquito species to transmit WNV could be modulated in different ecosystems by climatic factors such as temperature $[55,56]$.

Finally, as observed for malaria, plague and RVF, we suggest that WNV epidemiology has to be considered differently according to Malagasy ecosystems. This implies that WNV infections surveillance, including acute encephalitis (AE) surveillance, should be adapted according to epidemiological conditions.

\section{Conclusion}

The importance of WNV-associated AE in Madagascar is probably underestimated and data regarding burden of WNV diseases are sparse in the country. Migliani et al. detected, between January 2001 and June 2002,79 cases of AE in two hospitals of Antananarivo, the capital city of Madagascar, including $3 \%$ due to WNV infection [57]. A recent study described an imported case of AE due to WNV infection in La Réunion island and coming from the north-west of Madagascar [12]. A review performed by Jmor et al. [58] revealed a minimum incidence of AE syndrome for all age groups of 6.34 per 100,000 population in tropical countries. The increasing incidence of encephalitis due to emerging agents, such as Japanese encephalitis virus, WNV and tick-borne encephalitis virus is a new challenge for public health [58]. More work is needed to better estimate the real burden of AE associated to WNV infection. Thus, the identification of at-risk environments for WNV circulation in human in Madagascar island is a first step to target future studies on AE surveillance.

\section{Abbreviations}

AE: acute encephalitis

AIC: Akaike Information Criterion

Cl: confidence interval

ELISA: Enzyme Linked ImmunoSorbent Assay

GLMM: Generalized linear mixed model

IPM: Institut Pasteur de Madagascar

MAFE: Model-Averaged Fixed Effects 
NDVI: Normalized Difference Vegetation Index

OD: Optical Density

OR: Odd-Ratios

RVF: Rift Valley Fever

SES: socio-economic status

VIF: Variance Inflation Factors

WNE: West Nile Virus encephalitis

WNV: West Nile Virus

\section{Declarations}

\section{Ethics approval and consent to participate}

The protocol was approved by the Malagasy competent authorities, the Malagasy Ethic National

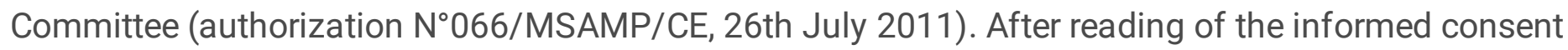
letter, written and oral informed consent was obtained from all participants. Participants were sampled by qualified investigators and the data were analyzed anonymously. All methods were carried out in accordance with relevant guidelines and regulations.

\section{Consent for publication}

Not Applicable

\section{Availability of data and materials}

The datasets used and/or analysed during the current study available from the corresponding author (soafy@pasteur.mg) on reasonable request.

\section{Competing interests}

The authors declare that they have no competing interests.

\section{Funding}

This study was supported by the Institut Pasteur de Madagascar (Internal Project through the ZORA (ZOonoses, Rodent and Arboviruses) project. Moreover, this material is based upon work supported by the Centers for Disease Control and Prevention (CDC; Cooperative Agreement \#U51/IP000327) and the U. S. Department of Homeland Security under the Center of Excellence of Emerging and Zoonotic Animal Diseases Grant Award Number 2010-ST061-AG0001. The views and conclusions contained in this paper 
are those of the authors and should not be interpreted as necessarily representing the official policies, either explicit or implicit, of the Centers for Disease Control and Prevention and the U. S. Department of Homeland Security. The funders had no role in study design, data collection and analysis, decision to publish, or preparation of the manuscript.

\section{Authors' contributions}

MMO: Conceptualization, Field coordination and achievement, Methodology, Data management, Statistical analysis, Project administration, Project supervision, Original draft Writing, Draft manuscript \& Editing

AB: Methodology, Laboratory analysis, Data management, Statistical analysis, Draft manuscript SFA: Conceptualization, Field coordination and achievement, Data management, Methodology, Project administration, Project supervision, Draft manuscript

ACD: Methodology, Laboratory analysis

JPR: Field collection, Laboratory analysis

SA: Field collection

FR: Methodology, revised manuscript

CR: Conceptualization, Methodology, Validation, revised manuscript

JMH: Conceptualization, Methodology, Project administration, Project supervision, Validation, Visualization, Draft manuscript.

All authors have given final approval of the version to be published.

\section{Acknowledgements}

We especially thank the population of Madagascar who participated to the studies. We thank those who facilitated the survey, i.e., heads of fokontany, local administration authorities and health authorities from Ministry of Health. We also thank the Plague Unit at the Institut Pasteur de Madagascar for data collection and supporting (S. Telfer, C. Rahaingosoamamitiana, F.M. Andriamiarimanana, S. Rahelinirina, M. Rajerison), S. Andrimasinoro for the management of data, B.S. Rahoilijaona H.A. Rakotoarison, H. Raharimampianina and A.M. Rakotohaingomahefa for their field supports. We thank G. Gray from the Division of Infectious Diseases of Duke University for supporting field collection.

\section{References}


1. INSTAT, DDSS, PNLP, IPM. Enquête sur les Indicateurs du Paludisme effectuée à Madagascar. Antananarivo: Roll Back Malaria; 2012 p. 128p. Available from https://dhsprogram.com/pubs/pdf/MIS9/MIS9.pdf

2. Duplantier J-M, Duchemin J-B, Chanteau S, Carniel E. From the recent lessons of the Malagasy foci towards a global understanding of the factors involved in plague reemergence. Vet Res. 2005;36: 437-453. doi:10.1051/vetres:2005007

3. Olive M-M, Grosbois V, Tran A, Nomenjanahary LA, Rakotoarinoro M, Andriamandimby S-F, et al. Reconstruction of Rift Valley fever transmission dynamics in Madagascar: estimation of force of infection from seroprevalence surveys using Bayesian modelling. Sci Rep. 2017;7: 39870. doi:10.1038/srep39870

4. Olive M-M, Chevalier V, Grosbois V, Tran A, Andriamandimby S-F, Durand B, et al. Integrated Analysis of Environment, Cattle and Human Serological Data: Risks and Mechanisms of Transmission of Rift Valley Fever in Madagascar. Barker CM, editor. PLoS Negl Trop Dis. 2016;10: e0004827. doi:10.1371/journal.pntd.0004827

5. Andriamandimby SF, Randrianarivo-Solofoniaina AE, Jeanmaire EM, Ravololomanana $L$, Razafimanantsoa LT, Rakotojoelinandrasana T, et al. Rift Valley fever during rainy seasons, Madagascar, 2008 and 2009. Emerg Infect Dis. 2010;16: 963-970. doi:10.3201/eid1606.091266

6. Morvan J, Rollin PE, Laventure S, Rakotoarivony I, Roux J. Rift Valley fever epizootic in the central highlands of Madagascar. Res Virol. 1992;143: 407-415. doi:10.1016/S0923-2516(06)80134-2

7. Morvan J, Fontenille D, Saluzzo JF, Coulanges P. Possible Rift Valley fever outbreak in man and cattle in Madagascar. Trans R Soc Trop Med Hyg. 1991;85: 108. doi:10.1016/0035-9203(91)90178-2

8. Morvan J, Chin LH, Fontenille D, Rakotoarivony I, Coulanges P. [Prevalence of antibodies to West Nile virus in youngsters from 5 to 20 years old in Madagascar]. Bull Soc Pathol Exot 1990. 1991;84: 225234.

9. Ratsitorahina M, Harisoa J, Ratovonjato J, Biacabe S, Reynes J-M, Zeller H, et al. Outbreak of dengue and Chikungunya fevers, Toamasina, Madagascar, 2006. Emerg Infect Dis. 2008;14: 1135-1137. doi:10.3201/eid1407.071521

10. Petersen LR, Roehrig JT. West Nile virus: a reemerging global pathogen. Emerg Infect Dis. 2001;7: 611-614. doi:10.3201/eid0704.010401

11. Yeung MW, Shing E, Nelder M, Sander B. Epidemiologic and clinical parameters of West Nile virus infections in humans: a scoping review. BMC Infect Dis. 2017;17. doi:10.1186/s12879-017-2637-9

12. Larrieu S, Cardinale E, Ocquidant P, Roger M, Lepec R, Delatte H, et al. A fatal neuroinvasive West Nile virus infection in a traveler returning from Madagascar: clinical, epidemiological and veterinary investigations. Am J Trop Med Hyg. 2013;89: 211-213. doi:10.4269/ajtmh.12-0003

13. Fontenille D, Rodhain F, Digoutte JP, Mathiot C, Morvan J, Coulanges P. Les cycles de transmission du virus West-Nile à Madagascar, Océan Indien. Ann Société Belge Médecine Trop. 1989;69: 233-243.

14. Cardinale E, Bernard C, Lecollinet S, Rakotoharinome VM, Ravaomanana J, Roger M, et al. West Nile virus infection in horses, Indian ocean. Comp Immunol Microbiol Infect Dis. 2017;53: 45-49. 
doi:10.1016/j.cimid.2017.06.006

15. Maquart M, Boyer S, Rakotoharinome VM, Ravaomanana J, Tantely ML, Heraud J-M, et al. High Prevalence of West Nile Virus in Domestic Birds and Detection in 2 New Mosquito Species in Madagascar. Coffey LL, editor. PLOS ONE. 2016;11: e0147589. doi:10.1371/journal.pone.0147589

16. Tantely ML, Goodman SM, Rakotondranaivo T, Boyer S. Review of West Nile virus circulation and outbreak risk in Madagascar: Entomological and ornithological perspectives. Parasite. 2016;23: 49. doi:10.1051/parasite/2016058

17. Randrianasolo L, Raoelina Y, Ratsitorahina M, Ravolomanana L, Andriamandimby S, Heraud J-M, et al. Sentinel surveillance system for early outbreak detection in Madagascar. BMC Public Health. 2010;10: 31. doi:10.1186/1471-2458-10-31

18. Andriamandimby SF, Olive M-M, Shimakawa Y, Rakotomanana F, Razanajatovo IM, Andrianinarivomanana TM, et al. Prevalence of chronic hepatitis B virus infection and infrastructure for its diagnosis in Madagascar: implication for the WHO's elimination strategy. BMC Public Health. 2017;17: 636. doi:10.1186/s12889-017-4630-z

19. Tantely LM, Cêtre-Sossah C, Rakotondranaivo T, Cardinale E, Boyer S. Population dynamics of mosquito species in a West Nile virus endemic area in Madagascar. Parasite. 2017;24: 3. doi:10.1051/parasite/2017005

20. Kilpatrick AM, Morales-Betoulle ME, Panella NA, Lanciotti RS, Powers AM, López MR, et al. West Nile Virus Ecology in a Tropical Ecosystem in Guatemala. Am J Trop Med Hyg. 2013;88: 116-126. doi:10.4269/ajtmh.2012.12-0276

21. Gray T, Webb CE. A review of the epidemiological and clinical aspects of West Nile virus. Int J Gen Med. 2014; 193. doi:10.2147/IJGM.S59902

22. Ohba S, Van Soai N, Van Anh DT, Nguyen YT, Takagi M. Study of mosquito fauna in rice ecosystems around Hanoi, Northern Vietnam. Acta Trop. 2015;142: 89-95.

doi:10.1016/j.actatropica.2014.11.002

23. Tantely ML, Le Goff G, Boyer S, Fontenille D. An updated checklist of mosquito species (Diptera: Culicidae) from Madagascar. Parasite Paris Fr. 2016;23: 20. doi:10.1051/parasite/2016018

24. Tantely LM, Boyer S, Fontenille D. A review of mosquitoes associated with Rift Valley fever virus in Madagascar. Am J Trop Med Hyg. 2015;92: 722-729. doi:10.4269/ajtmh.14-0421

25. Bargaoui R, Lecollinet S, Lancelot R. Mapping the Serological Prevalence Rate of West Nile fever in Equids, Tunisia. Transbound Emerg Dis. 2015;62: 55-66. doi:10.1111/tbed.12077

26. Nasci RS, Delorey MJ, Eisen RJ, Monaghan AJ, Fischer M, Hayden MH, et al. Meteorological Conditions Associated with Increased Incidence of West Nile Virus Disease in the United States, 2004-2012. Am J Trop Med Hyg. 2015;92: 1013-1022. doi:10.4269/ajtmh.14-0737

27. Chaintoutis SC, Dovas Cl, Danis K, Gewehr S, Mourelatos S, Hadjichristodoulou C, et al. Surveillance and Early Warning of West Nile Virus Lineage 2 Using Backyard Chickens and Correlation to Human Neuroinvasive Cases. Zoonoses Public Health. 2015;62: 344-355. doi:10.1111/zph.12152 
28. Khan SA, Chowdhury P, Choudhury P, Dutta P. Detection of West Nile virus in six mosquito species in synchrony with seroconversion among sentinel chickens in India. Parasit Vectors. 2017;10. doi:10.1186/s13071-016-1948-9

29. Montgomery RR, Murray KO. Risk factors for West Nile virus infection and disease in populations and individuals. Expert Rev Anti Infect Ther. 2015;13: 317-325. doi:10.1586/14787210.2015.1007043

30. Bin H, Grossman Z, Pokamunski S, Malkinson M, Weiss L, Duvdevani P, et al. West Nile fever in Israel 1999-2000: from geese to humans. Ann N Y Acad Sci. 2001;951: 127-142.

31. Harrigan RJ, Thomassen HA, Buermann W, Cummings RF, Kahn ME, Smith TB. Economic Conditions Predict Prevalence of West Nile Virus. Getz WM, editor. PLoS ONE. 2010;5: e15437. doi:10.1371/journal.pone.0015437

32. Robinson TP, Wint GRW, Conchedda G, Van Boeckel TP, Ercoli V, Palamara E, et al. Mapping the global distribution of livestock. PloS One. 2014;9: e96084. doi:10.1371/journal.pone.0096084

33. Rossi CA, Ksiazek TG. Enzyme linked immunosorbent Assay. Asan Institute for Life Sciences, School: Lee HW, Calisher C, Schmaljohn; 1998.

34. Clarke DH, Casals J. Techniques for hemagglutination and hemagglutination-inhibition with arthropod-borne viruses. Am J Trop Med Hyg. 1958;7: 561-573.

35. Barme M. Techniques des laboratoires des virus et des arbovirus. 19691970 pp. 168-169.

36. Hair JF, editor. Multivariate data analysis. 7. ed., Pearson new internat. ed. Harlow: Pearson; 2014.

37. Grueber CE, Nakagawa S, Laws RJ, Jamieson IG. Multimodel inference in ecology and evolution: challenges and solutions: Multimodel inference. J Evol Biol. 2011;24: 699-711. doi:10.1111/j.14209101.2010.02210.x

38. Park SH, Goo JM, Jo C-H. Receiver operating characteristic (ROC) curve: practical review for radiologists. Korean J Radiol. 2004;5: 11-18. doi:10.3348/kjr.2004.5.1.11

39. R Development Core Team. R: A Language and Environment for Statistical Computing. In: Vienna, Austria: the R Foundation for Statistical Computing. 2011.

40. Lê S, Josse J, Husson F. FactoMineR: An R Package for Multivariate Analysis. J Stat Softw. 2008;25: 1. doi:10.18637/jss.v025.i01

41. Fox J, Weisberg S. An $\{R\}$ Companion to Applied Regression. Second. Sage; 2011. Available: http://socserv.socsci.mcmaster.ca/jfox/Books/Companion

42. Bates D, Maechler M, Bolker B, Walker S. Fitting Linear Mixed-Effects Models using Ime4. Journal of Statistical Software. 2015: 51 pages.

43. Bartoń K. MuMIn: Multi-Model Inference. 2015. Available from https://cran.rproject.org/web/packages/MuMln/index.html

44. Robin X, Turck N, Hainard A, Tiberti N, Lisacek F, Sanchez J-C, et al. pROC: an open-source package for R and S+ to analyze and compare ROC curves. BMC Bioinformatics. 2011;12: 77. doi:10.1186/1471-2105-12-77 
45. Dellagi K, Salez N, Maquart M, Larrieu S, Yssouf A, Silaï R, et al. Serological Evidence of Contrasted Exposure to Arboviral Infections between Islands of the Union of Comoros (Indian Ocean). Aguilar PV, editor. PLoS Negl Trop Dis. 2016;10: e0004840. doi:10.1371/journal.pntd.0004840

46. Mease LE, Coldren RL, Musila LA, Prosser T, Ogolla F, Ofula VO, et al. Seroprevalence and distribution of arboviral infections among rural Kenyan adults: A cross-sectional study. Virol J. 2011;8: 371. doi:10.1186/1743-422X-8-371

47. Kuniholm MH, Wolfe ND, Huang CY-H, Mpoudi-Ngole E, Tamoufe U, LeBreton M, et al. Seroprevalence and distribution of Flaviviridae, Togaviridae, and Bunyaviridae arboviral infections in rural Cameroonian adults. Am J Trop Med Hyg. 2006;74: 1078-1083.

48. Wang W, Sarkodie F, Danso K, Addo-Yobo E, Owusu-Ofori S, Allain J-P, et al. Seroprevalence of West Nile Virus in Ghana. Viral Immunol. 2009;22: 17-22. doi:10.1089/vim.2008.0066

49. Lonchampt C, Migliani R, Ratsitorahina M, Rabarijaona LP, Ramarokoto CE, Rakoto Andrianarivelo M, et al. [Persistence of an endemic circulation of the West Nile virus in Madagascar]. Arch Inst Pasteur Madagascar. 2003;69: 33-36.

50. Leblond A, Sandoz A, Lefebvre G, Zeller H, Bicout DJ. Remote sensing-based identification of environmental risk factors associated with West Nile disease in horses in Camargue, France. Prev Vet Med. 2007;79: 20-31. doi:10.1016/j.prevetmed.2006.11.008

51. Tran A, Sudre B, Paz S, Rossi M, Desbrosse A, Chevalier V, et al. Environmental predictors of West Nile fever risk in Europe. Int J Health Geogr. 2014;13: 26. doi:10.1186/1476-072X-13-26

52. Hockett CW, Kightlinger L, Chuang T-W, Wimberly MC. Landscape-Level Spatial Patterns of West Nile Virus Risk in the Northern Great Plains. Am J Trop Med Hyg. 2012;86: 724-731. doi:10.4269/ajtmh.2012.11-0515

53. Durand B, Zanella G, Biteau-Coroller F, Locatelli C, Baurier F, Simon C, et al. Anatomy of bluetongue virus serotype 8 epizootic wave, France, 2007-2008. Emerg Infect Dis. 2010;16: 1861-1868. doi:10.3201/eid1612.100412

54. Sallam MF, Xue R-D, Pereira RM, Koehler PG. Ecological niche modeling of mosquito vectors of West Nile virus in St. John's County, Florida, USA. Parasit Vectors. 2016;9. doi:10.1186/s13071-016-1646-7

55. Vogels CBF, Fros JJ, Göertz GP, Pijlman GP, Koenraadt CJM. Vector competence of northern European Culex pipiens biotypes and hybrids for West Nile virus is differentially affected by temperature. Parasit Vectors. 2016;9. doi:10.1186/s13071-016-1677-0

56. Vogels CBF, Göertz GP, Pijlman GP, Koenraadt CJM. Vector competence of northern and southern European Culex pipiens pipiens mosquitoes for West Nile virus across a gradient of temperatures: West Nile virus transmission by mosquitoes. Med Vet Entomol. 2017;31: 358-364. doi:10.1111/mve.12251

57. Migliani R, Tehindrazanarivelo A, Rasamoelisoa J, Raobijaona H, Rakotonirina G, Ramamonjisoa J, et al. Epidémiologie des encéphalites aiguës à Antananarivo. Centenaire de l'Académie Nationale des Arts, des Lettres et des Sciences 1902-2002. Colloque Scientifique International: "Santé, Environnement et Développement"; 2002 Jul 24; Antananarivo. 
58. Jmor F, Emsley HC, Fischer M, Solomon T, Lewthwaite P. The incidence of acute encephalitis syndrome in Western industrialised and tropical countries. Virol J. 2008;5: 134. doi:10.1186/1743422X-5-134

\section{Tables}

Table 1: Descriptive and univariate analyses. 


\begin{tabular}{|c|c|c|c|c|c|}
\hline Tested variable & & Positive & Number & $\begin{array}{l}\% \\
\text { seroprevalence } \\
{[95 \% \mathrm{CI}]}\end{array}$ & $\begin{array}{l}\text { Chi2 / } \\
\text { generalized } \\
\text { linear model P- } \\
\text { value }\end{array}$ \\
\hline \multirow[t]{2}{*}{ Gender } & Female & 108 & 851 & $\begin{array}{l}12.7[10.5- \\
15.1]\end{array}$ & $\mathrm{p}>0.20$ \\
\hline & Male & 106 & 829 & $\begin{array}{l}12.8[10.6- \\
15.3]\end{array}$ & \\
\hline \multirow[t]{4}{*}{ Age } & 18 to 26 & 56 & 456 & $12.3[9.4-15.6]$ & $\mathrm{p}>0.20$ \\
\hline & 27 to 37 & 48 & 423 & 11.3 [8.5-14.8] & \\
\hline & 38 to 46 & 49 & 361 & $\begin{array}{l}13.6[10.2- \\
17.5]\end{array}$ & \\
\hline & $>47$ & 61 & 440 & $\begin{array}{l}13.9[10.8- \\
17.4]\end{array}$ & \\
\hline \multirow[t]{3}{*}{ Habitat } & Urban & 35 & 450 & 7.8 [5.5 - 10.7] & $\mathrm{p}<0.05$ \\
\hline & Sub-urban & 64 & 510 & $\begin{array}{l}12.5[9.8- \\
15.7]\end{array}$ & \\
\hline & Rural & 115 & 720 & $\begin{array}{l}16.0[13.4- \\
18.9]\end{array}$ & \\
\hline \multirow[t]{3}{*}{$\begin{array}{l}\text { socio-economic } \\
\text { status }\end{array}$} & Low & 148 & 847 & $\begin{array}{l}17.5[15.0- \\
20.2]\end{array}$ & $\mathrm{p}<0.001$ \\
\hline & Intermediate & 61 & 746 & $8.2[6.3-10.4]$ & \\
\hline & High & 5 & 87 & 5.7 [1.9-12.9] & \\
\hline \multirow{3}{*}{$\begin{array}{l}\text { Working } \\
\text { environment }\end{array}$} & Indoor & 35 & 499 & $7.0[4.9-9.6]$ & $\mathrm{p}<0.001$ \\
\hline & Outdoor & 145 & 924 & $\begin{array}{l}15.7[13.4- \\
18.2]\end{array}$ & \\
\hline & Household & 34 & 257 & 13.2 [9.3-18.0] & \\
\hline Frequent contact & No & 150 & 1,182 & $12.7[10.9-$ & $\mathrm{p}>0.20$ \\
\hline
\end{tabular}




\begin{tabular}{|c|c|c|c|c|c|}
\hline with poultry & & & & 14.7] & \\
\hline & Yes & 64 & 498 & $\begin{array}{l}12.9[10.0- \\
16.1]\end{array}$ & \\
\hline \multirow{2}{*}{$\begin{array}{l}\text { Frequent work in } \\
\text { rice field }\end{array}$} & No & 117 & 1,038 & 11.3 [9.4-13.4] & $\mathrm{p}<0.05$ \\
\hline & Yes & 97 & 642 & $\begin{array}{l}15.1[12.4- \\
18.1]\end{array}$ & \\
\hline \multirow{2}{*}{$\begin{array}{l}\text { Frequent work in } \\
\text { forest }\end{array}$} & No & 122 & 1,162 & 10.5 [8.8-12.4] & $\mathrm{p}<0.001$ \\
\hline & Yes & 92 & 518 & $\begin{array}{l}17.8[14.6- \\
21.3]\end{array}$ & \\
\hline \multirow[t]{4}{*}{ Poultry density } & $\begin{array}{l}<15.6 \text { per } \\
\mathrm{km} \square\end{array}$ & 70 & 420 & $\begin{array}{l}16.7[13.2- \\
20.6]\end{array}$ & $\mathrm{p}<0.001$ \\
\hline & $\begin{array}{l}15.6 \text { to } 37.2 \\
\text { per } \mathrm{km} \square\end{array}$ & 60 & 420 & $\begin{array}{l}14.3[11.1- \\
18.0]\end{array}$ & \\
\hline & $\begin{array}{l}37.2 \text { to } 75.9 \\
\text { per } \mathrm{km} \square\end{array}$ & 60 & 450 & $\begin{array}{l}13.3[10.3- \\
16.8]\end{array}$ & \\
\hline & $\begin{array}{l}>76.0 \text { per } \\
\mathrm{km} \square\end{array}$ & 24 & 390 & $6.2[4.0-9.9]$ & \\
\hline \multicolumn{2}{|l|}{ Factor 1} & I & I & I & $\mathrm{p}<0.20$ \\
\hline \multicolumn{2}{|l|}{ Factor 2} & I & I & I & $p<0.001$ \\
\hline \multicolumn{2}{|l|}{ Factor 3} & I & I & I & $\mathrm{p}<0.001$ \\
\hline \multicolumn{2}{|l|}{ Factor 4} & I & I & I & $\mathrm{p}<0.001$ \\
\hline \multicolumn{2}{|l|}{ Total } & 214 & 1,680 & $\begin{array}{l}12.7[11.2- \\
14.4]\end{array}$ & I \\
\hline
\end{tabular}

Table 2: Results from the multi-model inference approach for dataset analysis. 


\begin{tabular}{|c|c|c|c|c|c|c|}
\hline \multicolumn{2}{|l|}{ Variables } & \multirow{2}{*}{$\begin{array}{l}\text { MAFE }^{\mathrm{a}} \\
\text { Ref }\end{array}$} & $95 \% \mathrm{CI}$ & \multirow{2}{*}{$\begin{array}{l}\text { p- } \\
\text { value } \\
/\end{array}$} & \multirow{2}{*}{\begin{tabular}{l|} 
weight \\
1
\end{tabular}} & \multirow{2}{*}{$\begin{array}{l}\begin{array}{l}\text { Number of } \\
\text { models }\end{array} \\
10\end{array}$} \\
\hline Working environment & Indoor & & l & & & \\
\hline & Outdoor & 0.69 & $\begin{array}{l}{[0.21 \quad-} \\
1.17]\end{array}$ & $\begin{array}{l}< \\
0.01\end{array}$ & & \\
\hline & Household & 0.48 & $\begin{array}{l}{[-0.07 \quad-} \\
1.04]\end{array}$ & $\mathrm{NS}^{\mathrm{b}}$ & & \\
\hline \multirow{2}{*}{$\begin{array}{l}\text { Frequent contact with } \\
\text { rice field }\end{array}$} & No & Ref & l & I & 0.48 & 5 \\
\hline & Yes & 0.14 & $\begin{array}{l}{[-0.13 \quad-} \\
0.70]\end{array}$ & NS & l & l \\
\hline \multirow[t]{4}{*}{ Poultry density } & $<17$ per $\mathrm{km}$ & Ref & l & l & 0.84 & 10 \\
\hline & $\begin{array}{l}18 \text { to } 37 \text { per } \\
\mathrm{km} \square\end{array}$ & -0.41 & $\begin{array}{l}{[-1.27} \\
0.29]\end{array}$ & NS & I & I \\
\hline & $\begin{array}{l}38 \text { to } 77 \text { per } \\
\mathrm{km} \square\end{array}$ & 0.02 & $\begin{array}{l}{[-0.72 \quad-} \\
0.77]\end{array}$ & NS & I & I \\
\hline & $>77$ per $\mathrm{km}$ & -0.95 & $\begin{array}{l}{[-2.08 \quad-} \\
-0.19]\end{array}$ & NS & I & I \\
\hline Factor 1 & & -0.09 & $\begin{array}{l}{[-0.42 \quad-} \\
0.04]\end{array}$ & NS & 0.46 & 4 \\
\hline Factor 2 & & -0.91 & $\begin{array}{l}{[-1.32} \\
-0.51]\end{array}$ & $\begin{array}{l}< \\
0.001\end{array}$ & 1 & 10 \\
\hline Factor 3 & & 0.10 & $\begin{array}{l}{[-0.15} \\
0.57]\end{array}$ & NS & 0.47 & 6 \\
\hline Factor 4 & & 0.53 & $\begin{array}{l}{\left[\begin{array}{ll}0.19 & - \\
0.87\end{array}\right]}\end{array}$ & $\begin{array}{l}< \\
0.005\end{array}$ & 1 & 10 \\
\hline
\end{tabular}

${ }^{\mathrm{a}} \mathrm{MAFE}=$ Model-Averaged Fixed Effects

${ }^{\mathrm{b}} \mathrm{NS}=$ not significant 
Figures

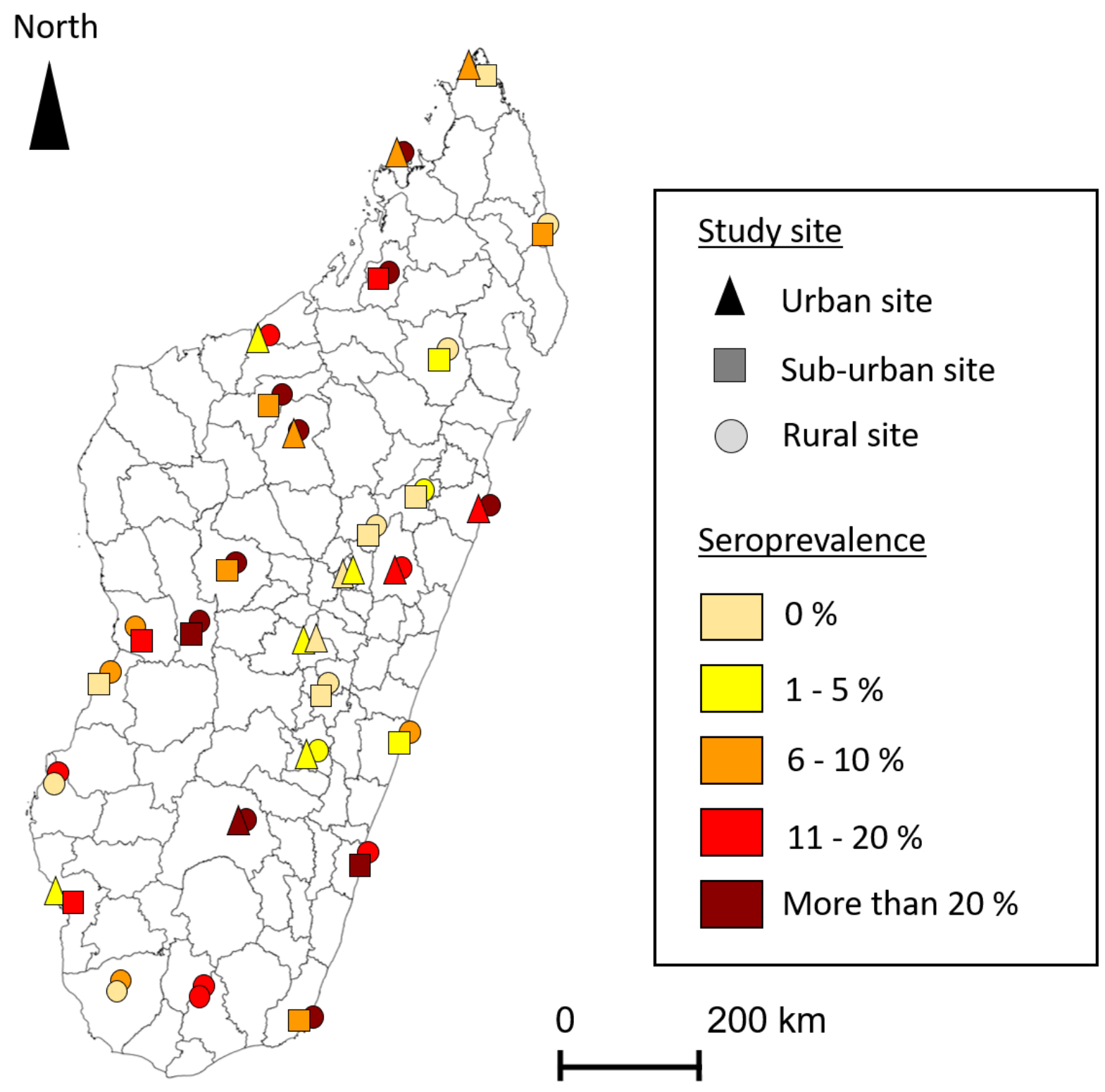

Figure 1

Sampling sites and IgG serological results. 